\title{
CONTRIBUTION TO THE STUDY OF THE FUNERARY ICONOGRAPHY IN UPPER MOESIA - REPRESENTATIONS OF PHYSICAL CONTACT ON ROMAN SEPULCHRAL MONUMENTS
}

\begin{abstract}
Roman tombstones were exhibited in a public space along the main roads directly outside towns and settlements. Carved reliefs and inscriptions on them provided information about the deceased and created the desired image of them using symbolism that was recognisable throughout the entire Roman Empire. This paper will inspect representations of physical contact on tombstones from the territory of the province of Upper Moesia. Dextrarum iunctio and family embraces were detected, occurring mainly on family portraits, within the same iconographic scheme as in other Danube provinces of the Empire.
\end{abstract}

KEY WORDS: FUNERARY MONUMENTS, ICONOGRAPHY, UPPER MOESIA, DEXTRARUM IUNCTIO, THE ROMAN PERIOD

\section{INTRODUCTION}

A special relationship with the past and a feeling of piety toward ancestors were deeply rooted in Roman society ${ }^{1}$. Awareness of the inevitable and often premature death put funerary customs and rituals of paying respect to the deceased at a very important place in Roman culture. One of the characteristics of Roman funerary practices were tombstones with engraved epitaphs and relief decorations with various motifs - floral ornaments, mythological scenes and characters, attributes of deities, portraits of the deceased, symbolic depictions and various other objects. This method of commemoration is characteristic of Roman

1 The article is the result of the project: Viminacium, Roman city and military camp - research of material and non- material culture of inhabitants by using the modern technologies of remote detection, geophysics, GIS, digitalization and $3 D$ visualization (no 47018), funded by The Ministry of Education, Science and Technological Development of the Republic of Serbia. culture, a custom which was carried along to the provinces with the migrations of the population.

Roman tombstones are an important source for studying the art of this period, as well as the social relationships and values of Roman society. Tombstones in the Roman period were exhibited in the necropolises, along the main roads leading to cities. Since the monuments were visible and displayed in a public space, they were often used as a medium through which the messages were transmitted to the local community, using commonly known visual symbols (Carroll 2013: 560). It was a place where people and their families could show how they saw themselves and how they wanted others to remember them.

Portraits (single or family) are one of the favourite motifs on Roman funerary monuments in the territory of the entire Empire (George 2005: 37; Mander 2012: 65). The images of the deceased are somewhat personalised, so, in addition to the standard portrayal, they can show specific elements of 
local costume, certain symbolic gestures or objects. For this reason, tombstones in Roman provinces can be indicators of social changes created by the interaction of the Roman and local populations.

\section{$* * *$}

In this paper we will discuss tombstones from the territory of the province of Upper Moesia, as well as provinces formed in its territory after administrative reforms at the end of the $3^{\text {rd }}$ century. Family portraits showing physical contact will be analysed, while mythological scenes will be excluded from this study. The chronological framework of this research is the period of the 1 st century, that is, the time of the formation of the province, until the $4^{\text {th }}$ century, when the latest monuments relevant to the topic are dated in the given territory.

\section{PHYSICAL CONTACT IN ROMAN FUNERARY ICONOGRAPHY}

The population of the Roman Empire shared a specific set of values, and the social norms were clear and expressed in a visible and recognisable way, both in speech and grammar, and in behaviour - the established symbolism of gestures and body language. Knowing these symbolic actions and the manner in which they are represented in art provides a better understanding of the culture of which they are a part (Corbeill 2004: 2).

Roman funerary iconography is uniform in its composition, but certain regional differences are reflected in the details, such as the type of costume, hairstyle, jewellery, as well as in the representation of certain poses and meaningful gestures, particular attributes or motifs. These peculiarities on tombstones often signified an affiliation to certain social groups or pointed to the family ties of various actors in the scene. Representations of physical contact on tombstones of the Roman period are fairly rare and represent an exception to a rule (George 2005: 43; Mander 2012: 68; Boat- wright 2005: 305). The analysis of funerary monuments from Italy and the western provinces of the Empire shows that physical contact can have different meanings depending on the context, despite the fact that we are often tempted to interpret each of them as an expression of closeness and familial affection (Mander 2012: 67). Depictions of physical contact between parents and children, as well as between spouses have been noted. The type of contact that occurs is dextrarum iunctio, or the handshake motif, and family embrace, a hug represented with a hand on the shoulder.

The motif of the handshake has been found on numerous objects of ancient art. It appears in Assyrian iconography, from which it was transferred to ancient Greek, and then to Etruscan and Roman art (Kuzmanović-Novović 2017: 115). This motif had a different meaning depending on the socio-cultural context and the chronological framework, but also on the type of object on which it was shown. In Greek funerary art, this motif, the so called dexiosis, occurs on stelae and lekithoi, where it symbolised the connection between the living and the dead, the separation in death and reunification in the afterlife (Davies 1985: 639; Kuzmanović-Novović 2017: 116). This motif appears frequently in Etruscan sepulchral art, primarily on urns and sarcophagi, and rarely in painted tombs. In this context, the motif symbolised parting in death, often between spouses, but also the promise of reunion in the otherworld. It can also be associated with marriage, emphasising the bond between the depicted individuals and symbolising marital happiness (Davies 1985: 631-632).

In Roman art, the dextrarum iunctio motif appears on a number of different objects - sculptures, coins, engagement rings and sepulchral monuments. In funerary art it is represented on sarcophagi, often within complex, biographical scenes, and on tombstones with family portraits. The display of this motif on Roman tombstones appears almost exclusively on the spouses' portraits. As part of the wedding ceremony, dextrarium iunctio in this context signified concordia, 
matrimonial harmony. Apart from the affection and the close bond of the depicted persons, this motif could also indicate the separation of the spouses due to the death of one of them, and the allusion to loyalty and love even in the afterlife (Davies 1985: 632-633; George 2005: 44; Mander 2012: 67-69).

The family embrace, which is expressed by laying a hand on one's shoulder, represents an act of closeness and affection between the spouses or parents and children. This meaningful gesture, however, may also be the symbol of parting due to death, a sign of mourning or of strengthening of the family ties, but also a way of highlighting the significance of some of its members. Choosing the type of contact, as well as the person initiating it, may be a mere coincidence, an artistic freedom, or a signature mark of the workshop, but it is more likely that it is a significant gesture that the ordering party requested (Mander 2012: 67-69).

\section{DEPICTIONS OF PHYSICAL CONTACT ON MONUMENTS OF UPPER MOESIA}

There have been several authors who have researched Roman tombstones from the province of Upper Moesia. During the first half of the $20^{\text {th }}$ century, N. Vulić made the greatest contribution to this topic, publishing inscriptions from this province on several occasions, sometimes with sketches and photographs, together with a brief description and commentary. Great success was achieved in the field of epigraphy, where the greatest contribution was made by Miroslava Mirković, Petar Petrović and Slobodan Dušanić. The most significant collection of published epigraphic monuments is the five publications of the Center for Epigraphics and Numismatics in Belgrade, Inscriptions de la Mésie Supérieure. Funerary monuments were also the research topic of a few doctoral dissertations and master theses (Kondić 1965; Pilipović, 2007), while several individual articles dealt with types of tombstones, or the symbolism of particu- lar motifs on them (Ђорђевић 1990; Milovanović 2001; Milovanović 2008; Milovanović 2013; Milovanović, Mrđić 2008; Pilipović 2004; Pilipović 2012; Tomović 1991).

\section{$* * *$}

Prior to the Roman conquest, there was no custom of raising stone tombstones with inscriptions and reliefs in the central Balkan region. This form of commemoration appeared with the arrival of the Roman army, which brought with it master masons. The earliest appearance of tombstones in Upper Moesia is recorded in the southern part of the province and coincides with the first deductions of veterans in the Scupi, at the end of the $1^{\text {st }}$ century AD (Petrovic 1975: 122). Big urban centres in other parts of the province soon developed their own workshops, probably in the $2^{\text {nd }}$ century. At that time the workshops in Singidunum, Viminacium, Ratiaria, Naissus, Ulpiana and Scupi probably existed (Tomovic 1993: 29). During the second half of the $2^{\text {nd }}$ century, workshops in smaller town centres, such as Timacum Minus, probably developed. The most intensive production of tombstones is recorded during the $2^{\text {nd }}$ and the first half of the $3^{\text {rd }}$ centuries (Petrović 1975: 123-124). At the end of the $3^{\text {rd }}$ and the beginning of the $4^{\text {th }}$ century, tombstones in the provinces formed in the territory of the former Upper Moesia are very scarce.

Among the Upper Moesian tombstones, the largest number was made in limestone, which was suitable for processing, long lasting and more affordable than marble. The most common form of monument is a funerary stele with a pediment (Petrović 1975: 49 - 50).

Depictions of physical contact were noted on 8 out of more than 50 tombstones, mostly displaying family portrait reliefs, from Upper Moesia ${ }^{2}$. Only one monument has a representation of the

2 Monuments from the Bulgarian part of Upper Moesia were excluded from this study due to the unavailability of appropriate literature. 


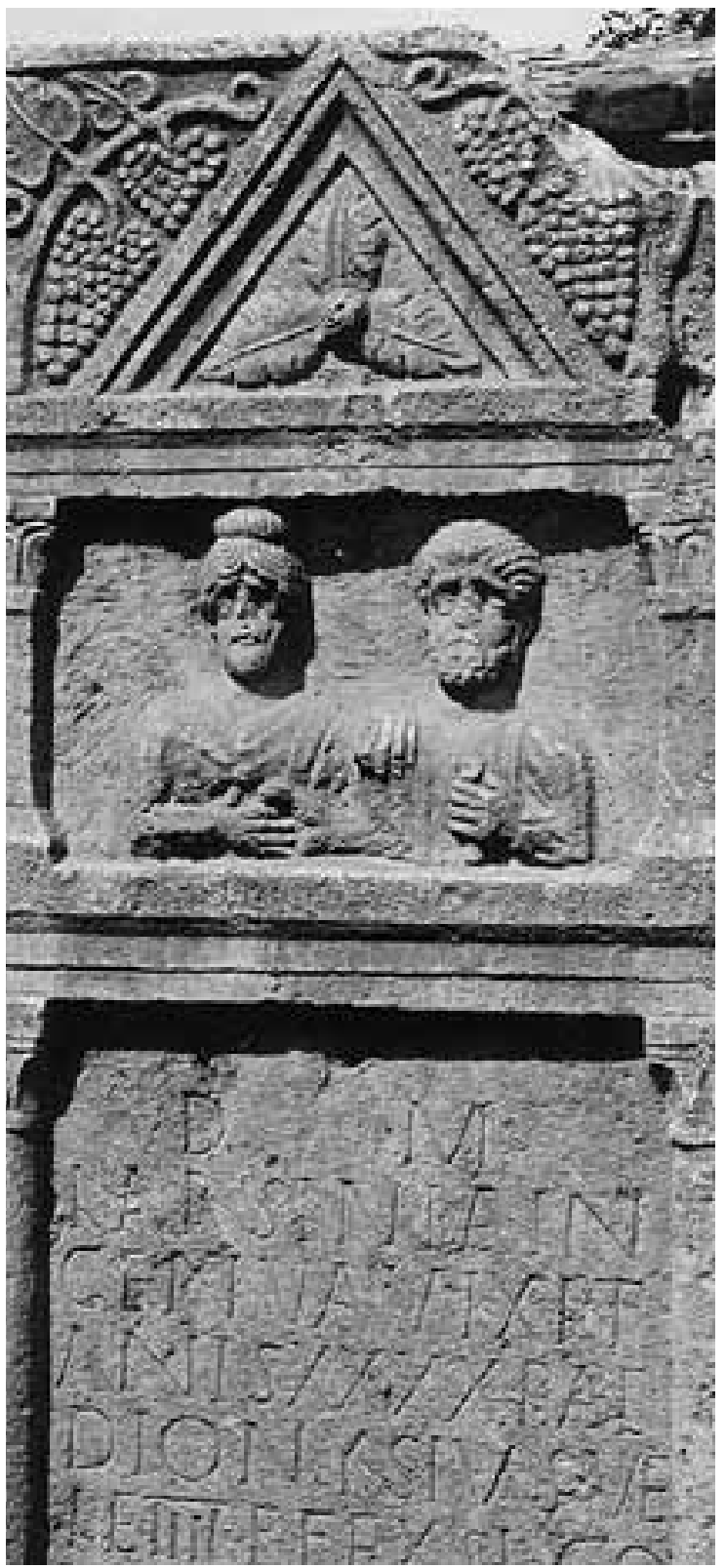

Fig. 1 - Stele of Larsinia Ingenua, Singidunum (http://www.ubi-erat-lupa.org)

dextrarum iunctio motif, while the others show an embrace with a hand on the shoulder.

On the stele of Larsinia Ingenua from Singidunum (cat. No. 1; fig. 1), two busts are shown in the niche below the pediment (Mirković, Dušanić 1976: 64-65). The spouses shake their right hands, and the woman lays her left hand on the right shoulder of the man. This is the only scene with a dextrarum iunctio motif on the tombstones from Upper Moesia.

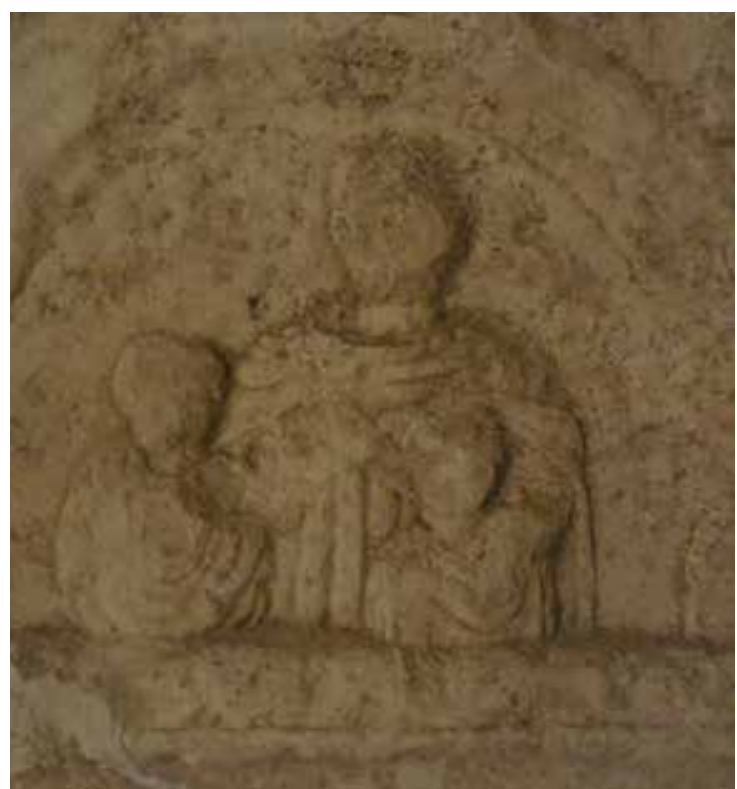

Fig. 2 - Family stele, Singidunum (photo by I. Kosanović)

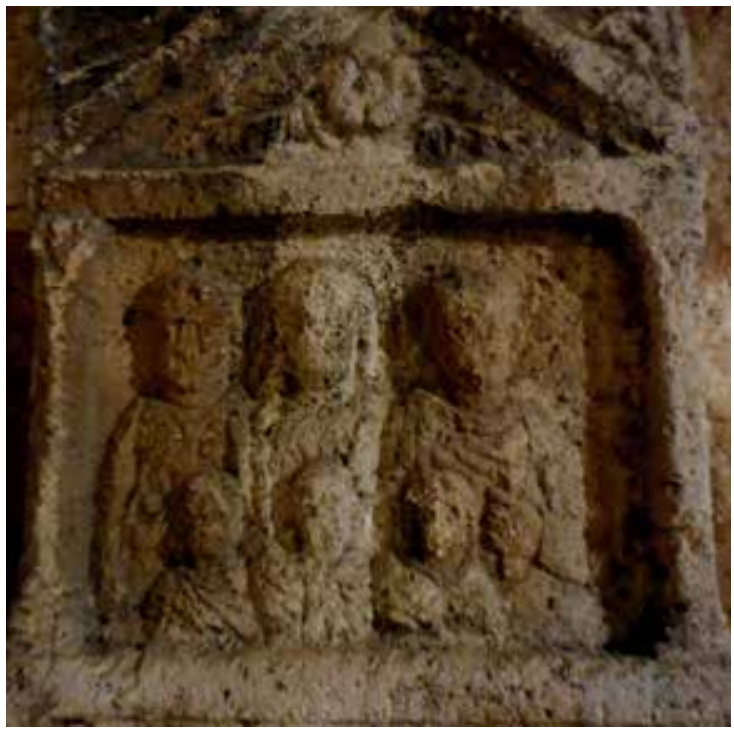

Fig. 3 - Stele of Nunius Priscianus, Singidunum (photo by I. Kosanović)

A monument from Singidunum (cat. No. 2; fig. 2) shows three busts on a pediment - an adult man and two children. A man with both hands hugs the children, the girl with the right, and the boy with his left hand. The girl is bigger than the boy, which corresponds to the ages of the children listed in the inscription. The parents dedicated the monument to their children and to their father's colleague or brother (Mirković, Dušanić 1976: 60). The man shown is probably the late Aurelius Eumenetus, 


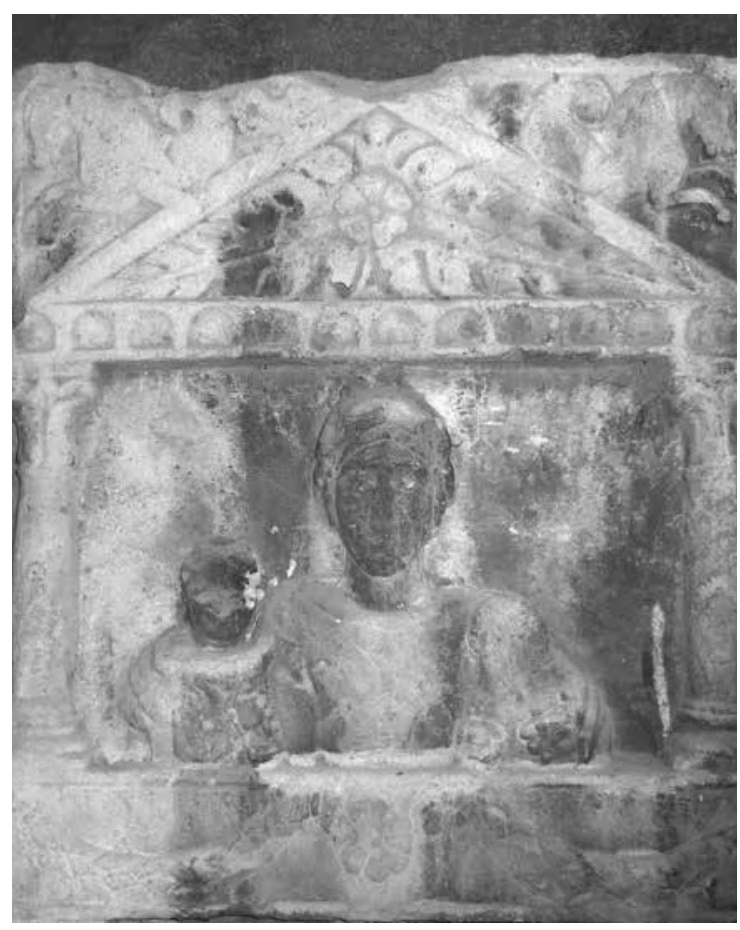

Fig. 4 - Monument of Aurelia Procla, Sopot (photo by I. Kosanović)

who may be the related to the children, so contact could signify family bonds, in this life and the next, since all three depicted persons are deceased.

On the stele of Nunius Priscianus, a young decurio of Singidunum (cat. No. 3; fig. 3), six people are shown in the niche below the pediment. There are two women and one man in the top row, with three children in front of them. The number of represented individuals does not correspond to the number of persons mentioned on the inscription (Mirković, Dušanić 1976: 71). An adult man and a woman in the middle placed their right hands on the shoulders of the children in front of them. The monument was raised by a man and a woman, probably the parents of the deceased; the inscription is partially damaged (one part is missing), so the nature of the contact is not clear enough.

The relief on the monument of Aurelia Procla, from Sopot (cat. No. 4; fig. 4) depicts a woman and two children, a bigger and a smaller one, in a rectangular niche. The woman is in the middle, hugging the children with both hands. The representation is not in accordance with the inscription, since the husband consecrates the monument to

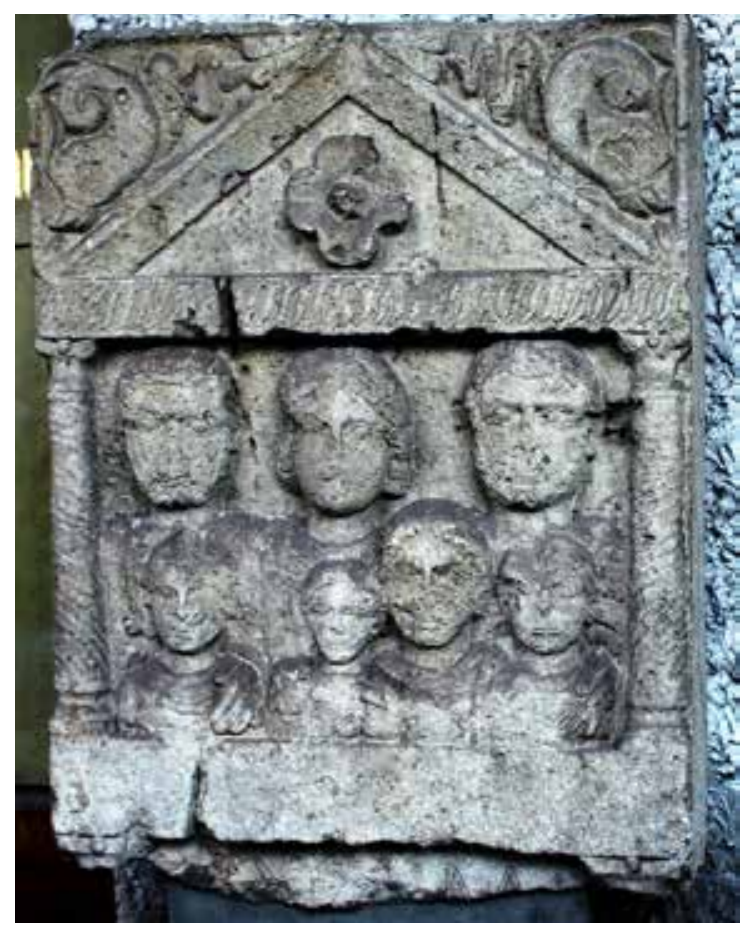

Fig. 5 - Funerary stele, Smederevo (https://mus.org.rs/)

the wife, and the children were not mentioned (Mirković, Dušanić 1976: 135). It is interesting that the monument of the woman is dedicated by a soldier of the Cohors II Aureliae Novae, who was still in service. It is possible that the display marks the parting of the deceased mother from the children, and they could be, for some unknown reason, not listed on the inscription.

On the funerary stele from Smederevo (cat. No. 5; fig. 5), seven busts are shown in a rectangular niche - in the top row there are two men and a woman, and four children in front of them (Mirković 1986: 170). This stele displays contacts between several people - all the adults have one or both hands on the shoulders of children in front of them. One of the children is shown slightly larger than the others and partly between the two lines of busts; it is possible that it is an older child, or someone who is different from the others in some way. Unfortunately, apart from a dedication to the gods of the underworld, the inscription is not preserved, so the shown contacts cannot be interpreted.

The spouses, an augustal and his wife, are shown on the stele of Titus Baebius from Vimi- 


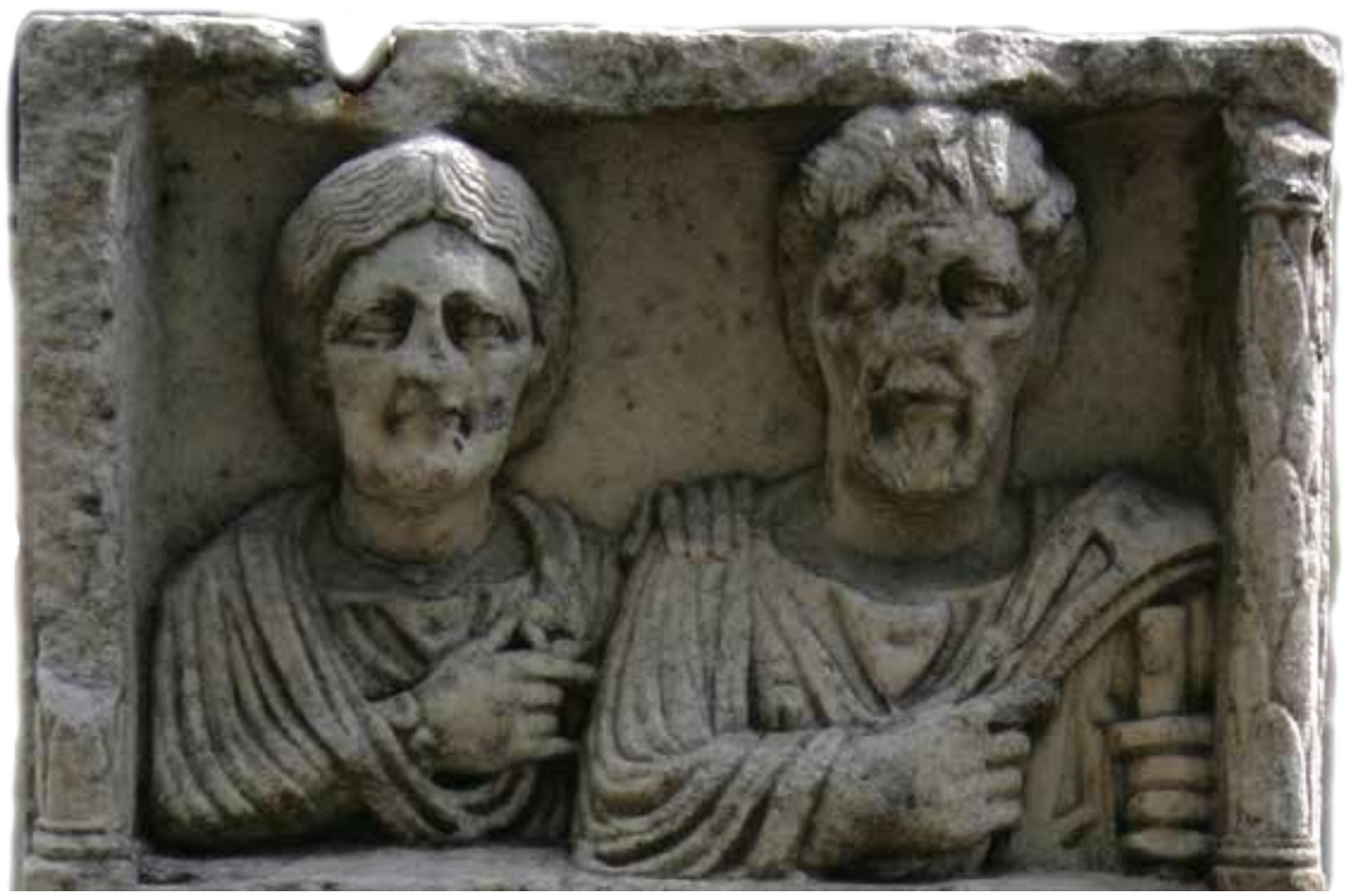

Fig. 6 - Stele of Titus Baebius, Viminacium (photo by N. Mrđić)

nacium (cat. No. 6; fig. 6). The monument is dedicated by an augustal, Titus Baebius Ascabantus, to his Titus Baebius Eutychus and his wife, Baebia Marcela. The augustal is married to his libertina, who also bears his name; her jewellery suggests a Celtic origin (Milovanović, Mrđić 2008: 92). Laying a hand on the shoulder of a husband potentially symbolises the separation due to his death, as only the husband is deceased at the moment of the monument's erection.

On the late Roman monument from Ravna (cat. No. 7; fig. 7), a relief shows three busts and three whole figures. The three busts are shown in the first row - two women and one man. There are two symmetrically shown horsemen in front of them, between whom there is a standing male figure with a corona on his head (Petrovic 1995: 91). The monument is dedicated by the parents and the sister to the deceased. A male individual in the upper row, probably the father, hugs his daughter, shown in the middle, with his right hand; the figures of horsemen probably denote the deceased sons. In this case, the physical contact may sym- bolise the strengthening of ties between the living members of the family.

The monument from Aleksinac (cat. No. 8; fig. 8), shows three persons in a niche, a man, a woman, and a child between them in the second row. The man is on the left, his face is not visible due to damage; his left hand is on the child's shoulder. On the right is a woman, her right hand is on the right shoulder of the man (Petrović 1979: 114). This monument is a consecration to the deceased son, and the touch potentially indicates parting in death.

\section{CONCLUDING REMARKS}

As previously discussed, family portraits on Roman tombstones are characterised by the standardisation of the composition, but also by the differences in specific details. Most often they depict spouses, sometimes with children, and rarely members of a wider family. Gestures, types of display and the position of individuals show different levels of identity of the depicted persons, and em- 


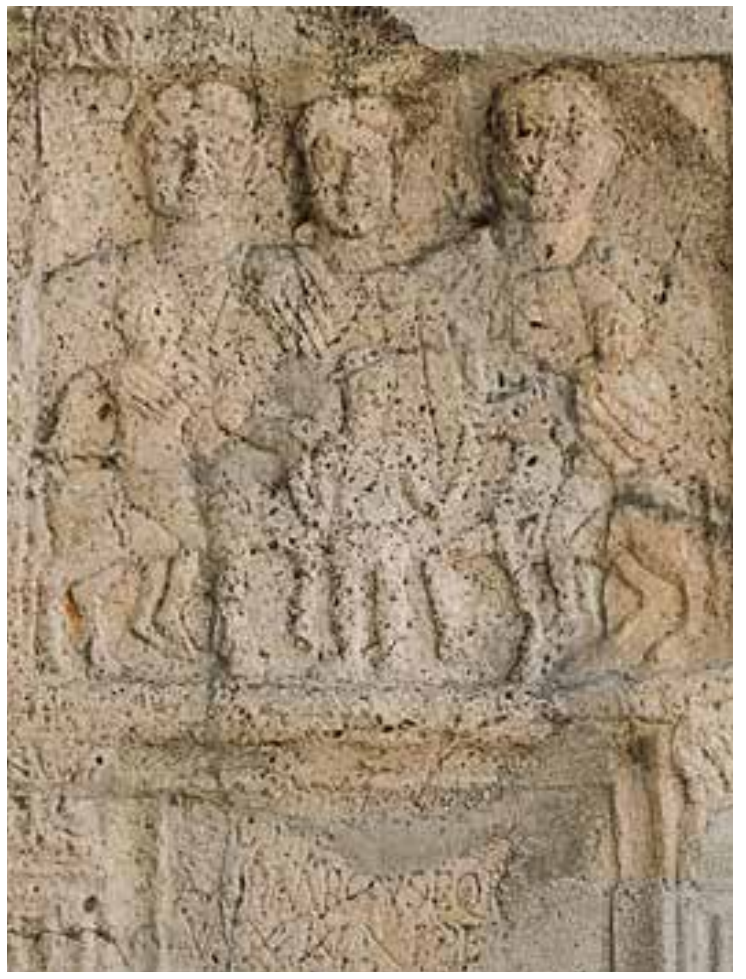

Fig. 7 - Family stele, Timacum Minus (http://www.muzejknjazevac.org.rs)

phasise the type of connection between them, as well as the family hierarchy (Mander 2012: 78).

The analysis of the distribution of physical contact motifs on Roman tombstones from the territory of Europe has distinguished two regions where this motif is frequent, Rome and Italy, and the Danube provinces. In other Western provinces, these motifs are extremely rare - from the territories of Gaul, Britain, Germany and Spain, there are a total of only 7 monuments with contact displays (Mander 2012: 70). The results are similar in Upper Moesia as in the Danube provinces. The number of monuments with depictions of contacts from this territory is insufficient for any statistically valid analysis, but it is useful to observe them from the perspective of provincial art, the system of values of the Roman society and Romanisation.

Among the analysed monuments, only one depiction of the dextrarum iunctio motif was noted. In this case, it is a monument that the former signifer and veteran of the legio IIII Flavia dedicated to his wife (cat. No. 1). Depictions of spouses' handshakes are common in monuments of mili- tary veterans and freedmen, because they emphasised a legally recognised marriage, a status that these groups did not have for a long time. It was probably a way to publicly show a newly acquired right of conubium (George 2005: 38-40; Mander 2012: 70, 80-81). Both persons on the Singidunum monument are Roman citizens, but the husband is a veteran of the legion, so it is possible that the dextrarum was used here to emphasise the recently gained right of legal marriage as well as the marital harmony of the couple.

Other analysed monuments (cat. Nos. 2-8) display the family embrace, expressed by laying a hand on one's shoulder. On all monuments the arm is shown anatomically inaccurately, in an unnatural position. The stonemason apparently did not intend to imitate natural movement, but rather show a gesture that denotes the bond and closeness. The display of the embrace contributed to the overall impression of a loving family, and in this way emphasis was placed on the pietas, mutual respect and emotional commitment of spouses, as well as par-

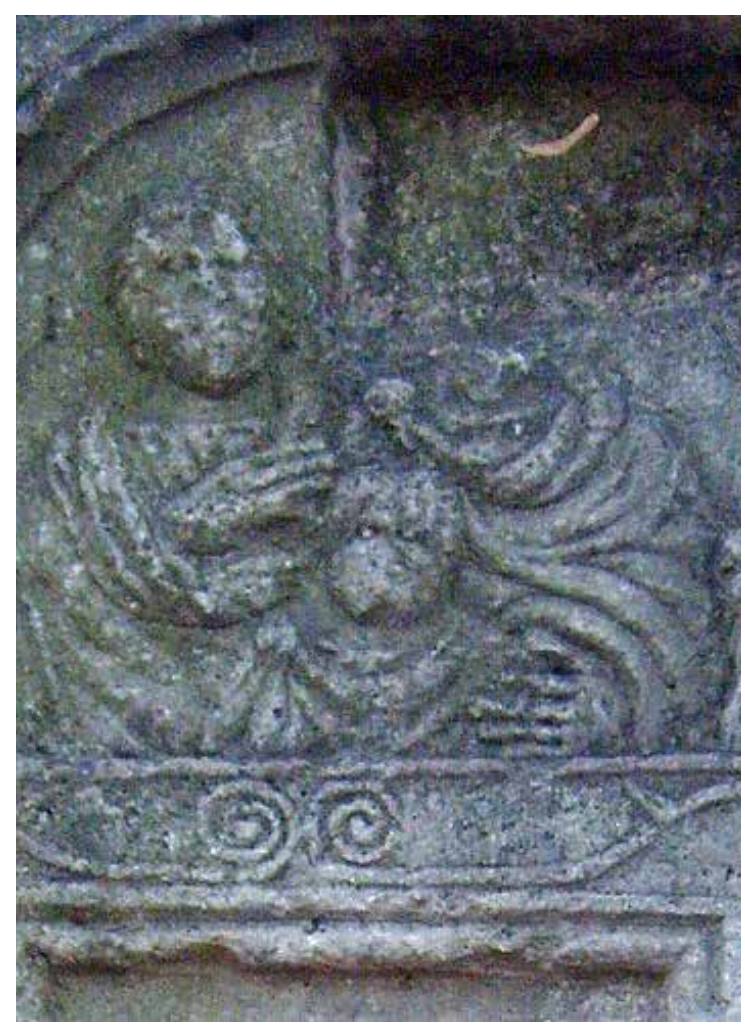

Fig. 8 - Stele of Publius Aelius Victor, Aleksinac (http:// edh-www.adw.uni-heidelberg.de/edh/foto/F024586) 
ents towards their children and vice versa (George, 2005: 41). On the Upper Moesian monuments these motifs, besides family harmony and closeness, could symbolise mourning and parting due to the death of one of the depicted persons, on whose shoulder the arm is usually placed. A unique case is the monument from Timacum Minus (cat. No. 7), where an embrace is shown between a father and a daughter, his only living child. In this case, the embrace could signify the strengthening of bonds between surviving family members.

A particular hierarchy in terms of initiating a contact is noted in all of the monuments. In a relationship between adults and children, the adults always initiate the contact, while in the relationship between husband and wife, the initiator is always the wife. Six monuments (cat. Nos. 2-5, 7-8) show adults who hug children and, two (cat. Nos. 6,8 ), show women who put their hand on the shoulder of the husband. On the monuments from the region of Rome and Italy, women usually initiate contact, while in the Danube provinces the iconography is somewhat more dynamic. This is striking in the case of Dacia, which shows a great deviation from the rules, because the contact is reciprocal on all monuments, that is, both spouses participate equally (Mander 2012: 73).

The distribution of the motif of physical contact points to a greater concentration in the eastern and northern parts of Upper Moesia, while these scenes are not recorded on monuments from the southern parts of the province. Monuments originate both from larger urban centres and from smaller settlements. Most of them are dated to the period of the $2^{\text {nd }}-3^{\text {rd }}$ century, while only one from Timacum Minus is late Roman.

\section{$* * *$}

In conclusion, it can be said that the motif of physical contact on Roman tombstones is a matter of strong regional affinities, and Upper Moesia fits into the wider picture of art in the Danube provinces. The depictions of physical contact in the funerary iconography indicate a very high degree of Romanisation in Upper Moesia, as early as the $2 n d$ century. This would indicate that, apart from mere artistic influences, elements of non-material culture were transferred to this province along with the developed, accepted and understood symbolism of these kinds of motifs, which reflected the social norms of the Roman Empire.

\section{ABBREVIATIONS}

IMS I - Inscriptions de la Mésie supérieure I. Singidunum et le Nord-Ouest de la province

IMS II - Inscriptions de la Mésie supérieure II. Viminacium et Margum

IMS III/2 - Inscriptions de la Mésie supérieure III/2. Timacum Minus et la Valée du Timok.

IMS IV - Inscriptions de la Mésie supérieure IV. Naissus - Remesiana - Horreum Margi

Arheologija i prirodne nauke (Archaeology and Science) is an Open Access Journal. All articles can be downloaded free of charge and used in accordance with the licence Creative Commons - Attribution-NonCommercial-NoDerivs 3.0 Serbia (https://creativecommons.org/licenses/bync-nd/3.0/rs/.

Časopis Arheologija i prirodne nauke je dostupan u režimu otvorenog pristupa. Članci objavljeni u časopisu mogu se besplatno preuzeti sa sajta i koristiti u skladu sa licencom Creative Commons - Autorstvo-Nekomercijalno-Bez prerada 3.0 Srbija (https://creativecommons.org/licenses/bync-nd/3.0/rs/.

\section{BIBLIOGRAPHY}

\section{Boatwright, M., T. 2005}

Children and Parents on the Tombstones of Pannonia. In: George, M. (ed.) The Roman Family in the Empire. Rome, Italy, and Beyond; Oxford: Oxford University Press: 287-318. 


\section{Carroll, M. 2013}

Ethnicity and Gender in Roman Funerary Commemoration: Case Studies from the Empire's Frontiers. In: Nilsson Stutz L., Tarlow, S. (Eds.) The Oxford Handbook of the Archaeology of Death and Burial. Oxford: Oxford University Press: 559-580.

\section{Corbeill, A. 2004}

Nature Embodied: Gesture in Ancient Rome. Princeton: Princeton University Press.

\section{Davies, G. 1985}

The Significance of the Handshake Motif in Classical Funerary Art. American Journal of Archaeology, Vol. 89, No. 4 (Oct., 1985): 627-640.

\section{George, M. 2005}

Family Imagery and Family Values in Roman Italy. In: George, M. (ed.) The Roman Family in the Empire. Rome, Italy, and Beyond; Oxford: Oxford University Press: 37-66.

\section{Ђорђевић, М. 1990}

Римски камени саркофази из Виминацијума, Viminacivm 4-5/1989-1990: 133-147.

(Đorđević, M. 1990

Rimski kameni sarkofazi iz Viminacijuma, Viminacivm 4-5/1989-1990: 133-147.)

\section{Kondić, V. 1965}

Sepulkralni spomenici sa teritorije rimske provincije Gornje Mezije, Doktorska disertacija, Filozofski fakultet, Univerzitet $\mathrm{u}$ Beogradu.

\section{Kuzmanović-Novović, I. 2017}

Dextrarum Iunctio in the Art of Antiquity. In: M. B. Vujović (ed.) Ante portam auream: studia in honorem professoris Aleksandar Jovanović. Belgrade: Faculty of Philosophy: 115-128.

\section{Mander, J. 2012}

The Representation of Physical Contact on Roman Tombstones. In: Harlow, M. and Larsson Lovén,
L. (eds.) Families in the Roman and Late Antique World; New York: Continuum International Publishing Group: 64-84.

\section{Milovanović, B. 2001}

Vegetabilni motivi na nadgrobnim spomenicima iz Viminacijuma, VIMINACIVM 12: 109-134.

\section{Milovanović, B. 2008.}

Simbolika prikazanih životinja na nadgrobnim stelama iz Viminacijuma, Arheologija i prirodne nauke 4: 15-25.

\section{Milovanović, B., Mrđić, N. 2008}

The She-Wolf Motif with Romulus and Remus on a Tomb Stela of an Augustal from Viminacium, In: Bollettino di Archeologia online, Volume Speciale (The XVII International Congress of Classical Archaeology meetings between Cultures in the Ancient Mediterranean, 22-23 Sept. 2008 in Roma), 90-94. Roma: Ministero per I Beni e le Attivita Culturali, http://151.12.58.75/archeologia/

\section{Milovanović, B. 2013}

Soldiers, medals and military insignia on tombstones from Viminacium, Vjesnik Arheološkog muzeja u Zagrebu XLVI, 3: 159-184

\section{Mirković, M., Dušanić, S. 1976}

Inscriptions de la Mésie supérieure I. Singidunum et le Nord-Ouest de la province. Beograd: Filozofski fakultet, Centar za antičku epigrafiku i numizmatiku.

\section{Mirković, M. 1986}

Inscriptions de la Mésie supérieure II. Viminacium et Margum. Beograd: Filozofski fakultet, Centar za antičku epigrafiku i numizmatiku.

\section{Петровић, П. 1975}

Палеографија римских натписа у Горњој Мезији. Посебна издања 14. Београд: Археолошки институт.

(Petrović, P. 1975

Paleografija rimskih natpisa u Gornjoj Meziji. 
Posebna izdanja 14. Beograd: Arheološki institut.) REZIME

PRILOG PROUČAVANJU

Petrović, P. 1979

FUNERARNE IKONOGRAFIJE U

Inscriptions de la Mésie supérieure IV. Naissus -

Remesiana - Horreum Margi. Beograd: Centre

d'Études Épigraphiques et Numismatiques.

GORNJOJ MEZIJI - PREDSTAVE

FIZIČKOG KONTAKTA NA

RIMSKIM NADGROBNIM

SPOMENICIMA

\section{Petrović, P. 1995}

Inscriptions de la Mésie supérieure III/2. Timacum

Minus et la Valée du Timok. Beograd: Centre d'Études Épigraphiques et Numismatiques.

\section{Pilipović, S. 2004}

Dolphin representations on stelae from Upper Moesia, BALCANICA XXXIV: 357-383.

\section{Пилиповић, С. 2007}

Мит и љубав. Представе на надгробним споменицима римске провинције Горње Мезије. Београд: Српска академија наука и уметности, Балканолошки институт.

(Pilipović, S. 2007

Mit i ljubav. Predstave na nadgrobnim spomenicima rimske provincije Gornje Mezije. Beograd: Srpska akademija nauka i umetnosti, Balkanološki institut.)

\section{Pilipović, S. 2012}

Free-Standing Medallions with Portraits in Upper Moesia. Revue des études anciennes, Annales de l)Université Michel de Montaigne - Bordeaux 3, Tome 114, $\mathrm{n}^{\circ} 1$ : 101-116.

Tomović, M. 1991

Prokoneski sarkofag sa girlandama iz Viminaciuma. Viminacium 6: 69-82

Tomović, M. 1993

Roman Sculpture in Upper Moesia. Monographies No. 24. Belgrade: Institute of Archaeology.

\section{KLJUČNE REČI: NADGROBNI SPOMENICI, IKONOGRAFIJA, GORNJA MEZIJA, DEXTRA- RUM IUNCTIO, RIMSKI PERIOD}

Rimska funerarna ikonografija obiluje simboličkim predstavama i motivima, koji su bili prepoznatljivi širom čitavog Carstva. U radu su analizirani prikazi fizičkog kontakta na rimskim nadgrobnim portretima sa tla provincije Gornje Mezije. Među ovim spomenicima na 8 primeraka uočen je fizički kontakt između pojedinih osoba, a registrovani su dextrarum iunctio, tj. rukovanje supružnika i zagrljaj izražen polaganjem ruke na rame. Ovi motivi doprinosili su celokupnom utisku ljubavi i porodične sloge, a mogli su da simbolizuju i tugu, rastanak usled smrti neke od prikazanih osoba, bračnu harmoniju, ojačavanje porodičnih veza. Analizirani spomenici pokazuju podudaranje sa vizuelnom simbolikom i sistemom vrednosti u Rimu i podunavskim provincijama. Predstave fizičkog kontakta u funerarnoj ikonografiji ukazuju na veoma visok stepen romanizacije u Gornjoj Meziji, uključujući elemente duhovne kulture, već u II veku n. e. 


\begin{tabular}{|c|c|c|c|c|c|}
\hline $\begin{array}{l}\text { cat. } \\
\text { No. }\end{array}$ & $\begin{array}{l}\text { se- } \\
\text { lected } \\
\text { bibli- } \\
\text { ogra- } \\
\text { phy }\end{array}$ & $\begin{array}{l}\text { represented } \\
\text { individuals }\end{array}$ & inscription & location & date \\
\hline 1 & $\begin{array}{l}\text { IMS I, } \\
35\end{array}$ & spouses & $\begin{array}{c}D(\text { is) M(anibus) / Larsinia In/genua } \\
\text { vixit / annis XXXX P. Ae(lius) / Di- } \\
\text { onysius ve(teranus) / le(gionis) IIII } \\
\text { F(laviae) f(elicis) ex si(gnifero) co/ } \\
\text { niugi bene / merenti pos(uit) }\end{array}$ & Singidunum & $\begin{array}{l}\text { the sec- } \\
\text { ond half } \\
\text { of the } 2^{\text {nd }} \\
\text { century }\end{array}$ \\
\hline 2 & $\begin{array}{l}\text { IMS I, } \\
28\end{array}$ & $\begin{array}{l}\text { one adult } \\
\text { and two } \\
\text { children }\end{array}$ & $\begin{array}{l}\text { D(is) M(anibus) / Aur(eliae) Dioge- } \\
\text { niae / vix(it) ann(os) IIII et / Aur(e- } \\
\text { lio) Diogeniano / vix(it) [an]n(um) } \\
\text { I/Aur(elius) Demetrius str(ator) / } \\
\text { co(n)s(ularis) leg(ionis) IIII F(la- } \\
\text { viae) et / Val(eria) Marcella f(iliis) } \\
\text { kariss(imis) / et Aur(elio) Eumeneti } \\
\text { str(atori) / leg(ati) leg(ionis) ei- } \\
\text { usd(em) v(ixit) a(nnos) XL / con- } \\
\text { tirunc(ulo) fratri / b(ene) m(erenti) } \\
\text { p(osuerunt) }\end{array}$ & Singidunum & $\begin{array}{l}\text { the } 2^{\text {nd }} \\
\text { century }\end{array}$ \\
\hline 3 & $\begin{array}{l}\text { IMS I, } \\
\quad 45\end{array}$ & $\begin{array}{l}\text { three adults } \\
\text { and three } \\
\text { children }\end{array}$ & $\begin{array}{l}\text { Dibus Manibus / Infernis Nun/nio } \\
\text { Prisciano / dec(urioni) col(oniae) } \\
\text { Sing(iduni) qui / vix(it) ann(os) } \\
X X X V I / \text { non dignus / c }<e>\text { lerius / } \\
\text { inf } /<r>\text { a decessit / Aur(elius) Pris- } \\
\text { cillianus / et Sept(imia) Lupercilla }\end{array}$ & Singidunum & $\begin{array}{l}\text { the sec- } \\
\text { ond half } \\
\text { of the } 3^{\text {rd }} \\
\text { century }\end{array}$ \\
\hline 4 & $\begin{array}{l}\text { IMS I, } \\
119\end{array}$ & $\begin{array}{l}\text { one adult } \\
\text { and two } \\
\text { children }\end{array}$ & $\begin{array}{l}\text { D(is) M(anibus) / Aur(elia) Procla } \\
\text { / vixit ann(is) / XXXIII tit(ulum) } \\
\text { p(osuit) / Aur(e)l(ius) Victor / mil(es) } \\
\text { c(ohortis) II Aur(eliae) n(ovae) SA/ } \\
\text { COR c(oniugi) b(ene) m(erenti) }\end{array}$ & Sopot & $\begin{array}{l}\text { the sec- } \\
\text { ond half } \\
\text { of the } 2^{\text {nd }} \\
\text { - the first } \\
\text { decades } \\
\text { of the } 3^{\text {rd }} \\
\text { century }\end{array}$ \\
\hline 5 & $\begin{array}{c}\text { IMS II, } \\
190\end{array}$ & $\begin{array}{l}\text { three adults } \\
\text { and four } \\
\text { children }\end{array}$ & $D(i s) M($ anibus $)[---$ & Smederevo & $\begin{array}{l}\text { end of the } \\
2^{\text {nd }}-3^{\text {rd }} \\
\text { century }\end{array}$ \\
\hline 6 & $\begin{array}{l}\text { Mi- } \\
\text { lova- } \\
\text { nović, } \\
\text { Mrđić } \\
2008\end{array}$ & spouses & $\begin{array}{c}\text { D(is) M(anibus) / T(itus) Baeb(ius) } \\
\text { Eutychi / Aug(ustalis) Mun(icipii) } \\
\text { Ael(ii)Vim(inacii) / qui v(ixit) a(nnis) } \\
\text { LXV et / Baebiae Marcel / lae eius } \\
\text { /T(itus) Baeb(ius) Abascan / tus } \\
\text { aug(ustalis) eiusdem / mun(icipii) } \\
\text { patronis }\end{array}$ & Viminacium & $\begin{array}{l}\text { middle } \\
\text { of }- \text { the } \\
\text { second } \\
\text { half of } \\
\text { the } 2^{\text {nd }} \\
\text { century }\end{array}$ \\
\hline
\end{tabular}




\begin{tabular}{|c|c|c|c|c|c|}
\hline $\begin{array}{l}\text { cat. } \\
\text { No. }\end{array}$ & $\begin{array}{l}\text { se- } \\
\text { lected } \\
\text { bibli- } \\
\text { ogra- } \\
\text { phy }\end{array}$ & $\begin{array}{c}\text { represented } \\
\text { individuals }\end{array}$ & inscription & location & date \\
\hline 7 & $\begin{array}{l}\text { IMS } \\
\text { III/2, } \\
42\end{array}$ & $\begin{array}{l}\text { two adults } \\
\text { and three } \\
\text { children }\end{array}$ & $\begin{array}{c}D(\text { is }) \text { M(anibus) / Aurel(ius) Marcus } \\
\text { eq(ues) Ro[m(anus)] / vix(it) an(nis) } \\
\text { X[--] / et Aurelius Marcianu[s] / } \\
\text { vix(it) an(nis) VII[ } \pm \text { ?] / Aurel(ius) } \\
\text { Martian[us] / vir egregiu[s] / pr(a) } \\
\text { ep(ositus) coh(ortis) II / A(ureliae) } \\
\text { D(ar)d(anorum) pater / [et] / Aurelia } \\
\text { Donata / mater et Aurel[i]/a Sever- } \\
\text { ina / soror se(!) su/pervivent[es] / } \\
\text { fili(i)s b(ene) [m(erentibus)] p(os- } \\
\text { uerunt) }\end{array}$ & $\begin{array}{l}\text { Timacum } \\
\text { Minus }\end{array}$ & $\begin{array}{l}\text { the sec- } \\
\text { ond half } \\
\text { of the } \\
3^{\text {rd }}-\text { the } \\
\text { first half } \\
\text { of the } 4^{\text {th }} \\
\text { century }\end{array}$ \\
\hline 8 & $\begin{array}{c}\text { IMS } \\
\text { IV, } 95\end{array}$ & $\begin{array}{l}\text { two adults } \\
\text { and one } \\
\text { child }\end{array}$ & $\begin{array}{l}D(i s) M(\text { anibus }) / P(\text { ublius) Ael(i- } \\
\text { us) Vic/tor vix(it) an(nis) / XVIII } \\
\text { tit(ulum) p(osuerunt) / P(ublius) } \\
\text { Ael(ius) Ius/tinus et Ae/lia Claudi/a } \\
\text { parent(es) / fil(io) pient(issimo) / et } \\
\text { sibi sit / t(ibi) t(erra) l(evis) }\end{array}$ & Aleksinac & $\begin{array}{l}\text { middle } \\
\text { of the } 2^{\text {nd }} \\
\text { century }\end{array}$ \\
\hline
\end{tabular}

Table with the catalogue of the stelae 